\title{
Symposium on TRIPs and TRIMs in the Uruguay Round: Analytical and Negotiating Issues
}

\section{Introduction and Overview}

\author{
Robert M. Stern
}

\begin{abstract}
$\widetilde{\mathbb{d}}$ HE Uruguay Round negotiations included three 'new' agenda items trade-related intellectual property rights (TRIPs); trade-related investment measures (TRIMs); and services - that had not been covered explicitly in previous GATT negotiations. While services issues have attracted a good deal of analytical attention, this is much less the case for TRIPs and TRIMs. In an effort to further the understanding of TRIPs and TRIMs, a study group was organised in 1988 to address the important issues. This effort was supported in part by grants from the Canadian Donner Foundation to the Centre for the Study of International Economic Relations of the University of Western Ontario and the Ford Foundation to the Institute of Public Policy Studies of the University of Michigan.

Besides myself, the original members of the study group included Alan V. Deardorff (University of Michigan), Keith E. Maskus (University of Colorado), Rachel McCulloch (Brandeis University), and Deborah Hurley (OECD Secretariat). The members of the study group had the benefit of discussing their work in progress at a one-day meeting convened in Washington, D.C. in April 1989. This meeting included several staff economists from US Government agencies and the World Bank as well as some economists from universities in the Washington area and from the Institute for International Economics. Many useful comments were obtained from those present.

We had planned originally to publish the study group papers in book form, but changes in commitments of some of those involved made this infeasible. It was decided accordingly to publish four of the study group papers as a symposium in
\end{abstract}

ROBERT M. STERN is Professor of Economics and Public Policy in the Department of Economics and Institute of Public Policy Studies, The University of Michigan, Ann Arbor, Michigan, USA. 
The World Economy. The papers on TRIPs include one by Alan V. Deardorff and another by Arvind Subramanian (GATT Secretariat) which was specially commissioned for the symposium, and papers on TRIMs by Rachel McCulloch and Keith E. Maskus. As an aid to the reader, it may be useful to summarise some of the main points that are made in these symposium papers.

In his paper on TRIPs, Deardorff discusses the welfare effects of extending patent protection to parts of the world where it is not now provided. Such extension of patent protection is one of the objectives of the larger negotiations on TRIPs in the Uruguay Round. Deardorff argues, based in part on a theoretical model which is elaborated in a separate paper, that extending patent protection to all countries of the world is unlikely to be globally optimal. He suggests instead that at least the poorest of developing countries should be exempted for this process.

This conclusion is based on considerations of both equity and efficiency. Extending patent protection to a country that does not now provide it, but enjoys free access to the products of invention elsewhere, creates several benefits for the part of the world where the invention takes place. These include both increased monopoly profits and access to additional invented goods. In the country to which patent protection is extended, however, while there is the benefit of additional inventions, there are also costs in the form of monopoly profits paid to inventors and distortion of consumer choice due to monopoly pricing. If patent protection were extended to all countries of the world, Deardorff argues that these costs would outweigh the benefits from the world point of view, so that global patent protection should be rejected on efficiency grounds. Further, since patent protection also involves a substantial transfer of welfare from the developing towards the developed world, equity considerations suggest that it should be the poorest of developing countries which are exempted from extended patent protection.

In his companion paper on TRIPs, Subramanian traces the evolution of intellectual property (IP) as a trade issue. He notes the developed country disappointment with the World Intellectual Property Organization (WIPO) in providing for greater IP protection and the hope that the GATT would become a more effective vehicle for such protection. At the same time, he observes that US IP-related actions have been initiated bilaterally against several developing countries under Section 301 of the US trade law, with the consequence that the multilateral process has been bypassed and possibly undermined.

The TRIPs negotiations in the Uruguay Round concern such issues as standards or norms of IP protection, enforcement, basic principles such as most-favoured nation and national treatment, dispute settlement, and transitional arrangements for developing countries. While the developed countries have some interests in common in the TRIPs negotiations, Subramanian argues that the issues are best viewed from a North-South perspective, with high tech, luxury goods, and entertainment industries in the developed countries pursuing an IP agenda designed to protect what they view as their rights. 
Subramanian analyses the welfare consequences of higher IP protection from the national and global standpoints, using a framework similar to Deardorff's. He contends that the most empirically plausible situation is one in which there is a small developing country that is capable of copying the technology or products for which IP protection is being sought. He notes in this case that there is a congruence of producing and consuming interests in countries where imitation is possible, and that, since the countries are small, IP protection is not needed insofar as there is unlikely to be a detrimental effect on R\&D in the developed countries. He concedes that a case can be made for greater IP protection when there is a large country, a need to protect the transfer of technology, or discrimination in favour of domestic producers. Nonetheless, there is a distinct possibility that higher IP protection could reduce global welfare and have adverse distributional consequences. By including TRIPs in the Uruguay Round negotiations, there was a possibility of designing tradeoffs to compensate developing countries that might be adversely affected by granting greater IP protection. But it appears, according to Subramanian, that US bilateral actions may have preempted the potentially successful workings of the GATT multilateral process.

In her paper on TRIMs, McCulloch notes that there has been increasing use of investment policies that have combined incentive measures with operating restrictions on investment. This complex of investment policies is intimately bound up with questions of national sovereignty and with strategic decision-making on the part of imperfectly competitive multinational firms. The TRIMs negotiations in the Uruguay Round are ostensibly focused on the trade effects of investment policies. But McCulloch argues that the empirical evidence on the trade distorting effects of the investment policies is by no means clear, and, further, that the policies are complicated depending on whether they have an impact on the distribution of rents between firms and host countries or the allocation of resources in production and trade. She concludes therefore that the TRIMs negotiations may be too narrowly conceived, and that national investment policies need to be addressed in their own right either in GATT or in some alternative forum.

Maskus and Eby also note the complexity of the policy objectives and definitions of TRIMs and the consequent difficulties that may be encountered in achieving a multilateral agreement on TRIMs in the Uruguay Round negotiations. The difficulties arise from the fact that while many of the developed countries seek to improve the access of their domestic firms to foreign markets, host developing countries are at the same time straining to protect themselves from perceived loss of sovereignty and from restrictive business practices which may accompany inward direct investment. Granted all of this, Maskus and Eby argue in favour of a limited agreement on TRIMs which would have somewhat narrow coverage and limited country membership. Their hope is that this would serve to sensitise GATT members to the harmful welfare consequences of TRIMs and possibly lead to further negotiations and liberalisation. 
Maskus and Eby note that there are narrow and broad definitions of TRIMs, with the spectrum including: (1) local content requirements; (2) export performance requirements; (3) trade-balancing requirements; (4) product mandating; (5) domestic sales requirements; (6) manufacturing limitations; (7) technology transfer and licensing requirements; (8) remittance limitations; (9) local equity requirements; and (10) investment incentives. It is important to distinguish both the direct and indirect trade impacts of TRIMs, which is unfortunately difficult to accomplish. Nonetheless, they argue that there is ample justification for international concern since TRIMs are imposed in an often arbitrary and discriminatory manner and without adequate political controls. If an agreement on TRIMs is possible, it should recognise the pertinence of a number of the existing GATT articles, the need for new GATT disciplines and procedures, and provide for the special circumstances and interests of developing countries. Perhaps the most realistic outcome of the Uruguay Round is for a TRIMs code that would have strong disciplines for the signatory nations and yet provide incentives for others to join eventually as the benefits of greater and more efficient international investment could become available to them.

These symposium papers on TRIPs and TRIMs are by no means the last word on the subjects. Nonetheless, they should prove valuable insofar as they clarify many important analytical and negotiating issues and problems that have arisen in the context of the Uruguay Round negotiations and no doubt will continue to be addressed in the future. 